Eija Yli-Panula, a Docent in Aerobiology, works as a Senior Research Fellow in Didactics of Biology and Geography in the University of Turku, Finland

Eila Jeronen, a Docent in Environmental Education in the University of Oulu, in Education for Sustainable Development in the University of Helsinki and in Biology Education in the University of Lapland, Finland.

Heidi Seiko-AhIström, Master of Science, qualified biology teacher, graduate student in the University of Turku

Elsa Ruotsalainen, Bachelor of Science, student in the Master of Science study program in the Unversity of Turku

\title{
EIJA YLI-PANULA
}

The University of Turku, Finland, eija.yli-panula@utu.fi

\section{EILA JERONEN}

University of Oulu, Finland, eila.jeronen@oulu.fi

\section{HEIDI SEIKO-AHLSTRÖM}

The University of Turku, Finland, heidi.seiko@gmail.com

\section{Important Biological Issues for Elementary Pupils - A Study of Elementary Pre-service Teachers' Conceptions}

\section{Abstract}

Previous studies show teachers' conceptions about subject matter influencing their teaching decisions. In the survey, it has been investigated what kind of conceptions elementary pre-service teachers have concerning the issues they find important in teaching and management of biology in order to provide adequate learning for Finnish elementary school pupils. Totally 267 participants answered the questionnaire. The data was analysed by inductive content analysis. Biological content knowledge (60\%), skills (15\%), and experience (11\%) formed the greatest part of the mentioned important issues (totally 936). Other ones (e.g. attitudes, teaching) comprised less than $10 \%$. The issues of knowledge were mentioned significantly more often than the other ones. The results show that the participants had hardly any view of the totality concerning elementary biology education. So, teacher educators should discuss and implement new strategies to make biology education more comprehensive for elementary pre-service teachers.

\section{INTRODUCTION}

In this survey, it has been investigated what kind of conceptions the elementary pre-service teachers (EPT) find important in teaching and management of biology in order to provide adequate learning for the Finnish elementary pupils. Adequate learning in this study means the subject content knowledge (SCK) and pedagogical content knowledge (PCK), which are in line with the aims of the National 
core curriculum for basic education (NCC). Teachers' views and attitudes about subject matters influence their curricular and instructional decisions (Carlesen, 1991). What is thought to be important plays a crucial role when teachers plan the aims for their teaching, for a pupil's individual learning, and for the whole of the pupils' learning process. On the one hand, conceptions of important issues vary from one teacher to another. However, from the point of view of the subjects, every subject has fundamental factors which should be taken into account. On the other hand, an individual's conceptions of his/her own knowledge are highly correlated with his/her self-efficacy, shape his/her cognitions, and affects his/her behaviour (Bandura, 1986, 2004). Thus, a teacher's perceived knowledge and his or her conceptions of what is important act as a promoting or preventing factor when he or she carries out his or her tasks in practice (Tobias \& Everson, 1996).

One of the international goals for the future is the construction of a sustainable society (Fadel, Bialik, \& Trilling, 2015, 1-6). Education is a key for understanding how to do it and science education opens ways for it (Hurd, 2002). Teachers have a crucial role when pupils learn to understand scientific information concerning human being, environment, community, and society (Vauras, Lehtinen, Volet \& the SciLes research group 2014; Volet, Vauras, Khosa, \& Iiskala, 2013; Yli-Panula, Hiilovaara-Teijo \& Vauras 2015). The European Commission (2004) held school science education responsible for failing to attract pupils' interest in scientific issues. A reason for this situation can be found in science subjects and how they are taught (Osborne \& Dillon, 2008). In this sense, the following issues are important (Fadel et al., 2015, 25): 1) what we know and understand, 2) how we use what we know, and 3) how we behave and engage in the information in real life in the world. Through searching information (Volet, Summers, \& Thurman, 2009) and producing knowledge in groups (Khosa \& Volet, 2014), evaluating learning, action, and knowing together (Volet et al., 2013) the acquisition of scientific knowledge and collaboration is learned (Vauras et al., 2014; Yli-Panula et al., 2015). Through different learning environments self-efficacy, autonomy, and engagement are supported, and using current and contextual tasks, creativity and flexibility can be fostered (Turner \& Fulmer, 2013). It is also important to support pupils' emotional life (Vauras et al., 2014). These ideas have been emphasized also by Finnish researchers (e.g. Lavonen, 2013; Palmberg, Berg, Jeronen, Kärkkäinen, Norrgård-Sillanpää, Persson, Vilkonis, \& Yli-Panula, 2015; Uitto, Kärnä \& Hakonen, 2013), and they have been taken into account in the NCC (Opetushallitus, 2014, 2015, 10).

Research on elementary school teachers' knowledge of science reveals that a significant number of the elementary school teachers lack the CK and PCK needed to teach essential scientific ideas (Abell \& Smith, 1994; Bencze \& Hodson, 1999). Gaps in the knowledge and skills influence pupils' learning. Boström (2004) draws attention to the fact that individuals' learning-related preferences are half biological and half learnt. While some preferences are innate, the learnt half of a person's learning preferences is rooted in how the pupil has been taught to learn. Based on the previous ideas, it seems that both perceived knowledge and CK and PCK should be taken into account in teaching and learning practice.

In order to understand any phenomenon, it is necessary to examine it from different perspectives. Although studies in science education on EPTs' CK (e.g. Davis, Petish, \& Smithey, 2006; Opwood \& Souque, 1985) and PCK (e.g. Abd-el-Khalick, 2006; Appleton, 2003; Nilsson \& Loughran, 2012) have been published both in other countries and in Finland (Palmberg, 2012; Palmberg, Jeronen, Svens, Yli-Panula, Andersson, \& Jonsson, 2012; Palmberg, Jonsson, Jeronen, \& Yli-Panula, 2016 ). We are unaware of any study that examines the issues, which this investigation is focused on.

\section{THE RESEARCH AIM AND OUESTIONS}

In the study it has been investigated what EPT found to be important in teaching and management of biology to provide adequate learning for Finnish elementary school pupils. Based on the results, the 
biology curriculum and instruction in elementary teacher education will be developed. The previous ideas, described above, lead to the following research questions:

1. What do EPT regard as important in teaching and management of biology, and how do the issues vary between the groups?

2. How do the conceptions of EPT about important issues relate to biological content knowledge (BCK), PCK, and the Finnish NCC and the Curriculum of the Teacher Education (CTE) in biology?

As background information we wanted to know:

3. What kind of perceived knowledge of the biological issues do EPT have based on their self-estimations, and are there differences between the groups?

In accordance with the research question 3, as a further task is to discuss what EPTs' self-estimations of their perceived knowledge tell about their self-efficacy and their capability and willingness to work on matters they find important in biology and biology management in elementary schools.

\section{SUBJECT CONTENT KNOWLEDGE AND PEDAGOGICAL CONTENT KNOWLEDGE}

SCK is the fundamental issue for teaching and a certain amount of it, so called basic knowledge, is a pre-requisite for sophisticated PCK (e.g. Appleton, 2003; Käpylä, Heikkinen, \& Asunta, 2009; Magnusson, Krajcik, \& Borko, 1999). According to the Finnish EPT, basic knowledge includes human biology, e.g. blood circulation, liver function, brains, and homeostasis (Palmberg et al., 2012) and according to the Danish, Finnish, and Swedish EPT also ecological matters (photosynthesis, ecosystems, the distribution of rainforests, deserts, and groundwater), the biosphere, fish cultivation, and succession (Palmberg et al., 2016).

The definition of PCK varies among researchers (Bishop \& Denley, 2007; Käpylä et al., 2009; Magnusson et al., 1999; Shulman, 1987). According to Shulman (1987), PCK encompasses knowledge of student's perceptions, understanding and alternative conceptions of specific topics in the subjects, knowledge of curriculum and standards, instructional strategies, and representations for teaching specific subject matters. Based on Magnusson et al. (1999) and Käpylä et al. (2009), the PCK includes curricular teaching and learning goals of certain subjects, the knowledge of teaching methods, remembering and understanding biological issues, science teaching orientation, conceptual problems of pupils, and content-specific assessment methods. Bishop and Denley (2007) highlight it as a sophisticated process of combining knowledge bases together for particular contexts in relation to groups, topics or other factors. As such, PCK is seen as a dynamic form of knowledge that is constantly expanding and being transformed from other forms of teacher knowledge through teachers' experiences of planning, conducting, and reflecting on (science) teaching and learning.

The teacher is the most important contributor to learning (Committee on Science and Mathematics Teacher Preparation, 2001). However, EPT have naive conceptions about the teaching of science (Otero \& Nathan, 2004) and problems in choosing the most important content (Frändberg \& Bach, 2009; Käpylä et al., 2009). A great part of their knowledge is content specific and is limitedly applied to other situations such as to pupils' everyday life or even to students' understanding. They lack competence and qualifications to teach phenomena, to choose and bring up matters that are important for students with regard to the understanding of central issues in science. (Käpylä et al., 2009). Frändberg and Bach (2009) also showed that elementary teachers, who did not have nature-related studies in their curriculum, lack general entry requirements to choose student-centred teaching methods suitable for their students. Thus learning difficulties may arise when the teacher does not have established teaching methods appropriate to support the learning of a pupil (Haapasalo, 2004). Andree 
(2007) and Lundin (2007) state that the chosen and used student-centred teaching methods cannot be introduced without theoretical background and support of the subject.

In a study by Käpylä et al. (2009) comparing Finnish EPT (“content novices”) and pre-service biology teachers, the most common educational need mentioned by EPT was CK followed by content-specific teaching methods. They had in science more fractured and inadequate CK and misconceptions, and the connections between concepts were not as clear as those of the pre-service biology teachers. With regard to the PCK of the science curriculum, EPT noticed fewer relevant matters to learn, and describing them was more difficult compared to the pre-service biology teachers. The pre-service biology teachers were partly aware of students' scientific, conceptual problems, whereas EPT were not at all.

\section{TEACHING AND LEARNING CK AND PCK}

CK and PCK are both connected to skills, values, and attitudes in teaching and learning processes. The general skills such as concentration, apprehension, remembering, processing, time management, subject-specific teaching skills such as critical thinking, creative thinking, scientific collaboration, and communication are important (Ennis, 1989). Critical thinking is reasonable reflective thinking that is focused on deciding what to believe or do (Norris \& Ennis, 1989). In science, basic knowledge has subject specificity, empirically based subject specificity, and topic specificity, and finding and understanding basic knowledge requires critical thinking (Ennis, 1989). Creative thinking focuses on exploring ideas, generates possibilities, and looks for many right answers rather than just one (De Bono, 1969). It means, e.g. creating experimental study plans, telling environmentally oriented stories or playing teaching games. Scientific collaboration means, e.g. team building and setting biological teaching goals together. So, a teacher should also be able to evaluate e.g. biological knowledge and usage of biological concepts because during communication individuals exchange information through symbols, signs, or behaviour (Merriam Webster, www.merriam-webster.com/dictionary/ communication).

In this study, the answers where CK was connected to skills (e.g. species identification skills), to values (how to act in the nature to appreciate the nature values), to attitudes (e.g. to behave according to sustainable development), and to experiences (e.g. everyday life experiences, experiential learning) were counted as PCK.

\section{Perceived KnOWLedge ANd Self-efficACy AS A PROMOtIng OR PREVENTING ISSUe}

Mellado (1998) stated that pre-service teachers bring the concepts, opinions, and attitudes regarding teaching with them when they start their university education. This perceived knowledge they utilize when understanding and developing new knowledge (Tobias \& Everson, 1996). Therefore, when developing the biology curriculum and instruction in elementary education and elementary teacher education, it is good to know what EPT find important in biology education.

Teachers' and students' perceptions of their own knowledge are highly correlated with their self-efficacy (Bandura 1986, 2004). The self-efficacy can promote or prevent the person, e.g. to teach some issues (cf. Tobias \& Everson, 1996). People who strongly trust their abilities dare to use demanding thinking skills and are willing to act persistently to reach their goals (Bandura, 1986).

In this study, EPTs' self-estimations of their perceived knowledge were used as background information reflecting their self-efficacy, and willingness and capability to carry out biology teaching tasks. 


\section{BIOLOGY IN THE FINNISH NATIONAL CORE CURRICULUM FOR BASIC EDUCATION AND IN THE CURRICULUM OF TEACHER EDUCATION}

NCC (Opetushallitus, 2014, 2015) and the curricula for teacher education in independent universities include headlines, objectives, CK, and PCK (teaching methods and criteria for achievements) in individual subjects.

NCC guides work in the grades 1-6 (aged 7-12) and the grades 7-9 (aged 12-15). Education is based on the pupils' personal development, respect of life, human rights, and education for sustainable life habit. Local curricula are structured by teachers either utilizing traditional, subject-based knowledge or modern integrative, interdisciplinary knowledge (Opetushallitus, 2014, 2015, 10-17). So, every school has its own curriculum, where it implements the content and the aims for teaching and learning processes as appropriate to the school, to its specialization, and to the surrounding nature; e.g. the main topic in "Baltic Sea schools" (the schools in the Baltic Sea area) is the sea ecosystem, while in Lake Finland it is the lake ecosystem, and in Forest Finland the forest ecosystem. Although the realization and accomplishment vary from school to school, the focus of the teaching has to be in line with NCC.

BCK broadens and deepens from one grade to another. In the grades 1-6, biology belongs to the environmental studies, and in the grades $7-9$, it is a separate subject. Besides biology the environmental studies include geography, physics, chemistry, and health education. Teaching is based on scientific knowledge as a goal for cognitive development. Children should know and understand phenomena in nature and the built environment, themselves and other human beings, and the meaning of health and well-being. (Opetushallitus, 2015, 239-241.) In the grades 7-9, pupils study the structure of ecosystems, population and organisms, biodiversity, heredity and evolution, and the structure and function of the human body. In all grades, PCK includes skills for nature observation, for laboratory and field work, and scientific thinking. Pupils should also develop their environmental relationships and awareness, skills for sustainable future, and understanding of ethical questions. They should get feedback supporting their motivation and development of study skills. (Opetushallitus, 2015, 46-56, 271-274, 439-441.)

The focus in the CTE (Kasvatustieteiden tiedekunta, 2014) in biology studies has been on PCK, in research orientation such as process skills, scientific thinking, problem solving, reasoning, and ICT (Niemi \& Jakku-Sihvonen, 2006; Lavonen \& Juuti; 2012). In addition, the biological concepts, and evaluation guidelines mentioned in NCC have been in focus (Kasvatustieteiden tiedekunta, 2014) because the university teacher educators are asked to follow NCC. Teacher educators supervise teaching practice and have thus direct influence in schools. They can negotiate about CK and PCK, disciplinary policies and assessment, and develop the local curriculum with teachers. They can also support teachers to choose teaching, studying and learning methods, textbooks, and matters depending on teachers' decisions (Evagorou, Dillon, Viiri, \& Albe, 2015).

\section{MATERIALS AND METHODS}

\section{Study Design}

This study is a part of the project concerning EPTs' BCK and PCK. EPT are university students studying to become primary-school teachers (for grades 1-6). Their major is education. Totally 267 first year EPT participated in the study as volunteers. The sample is large. According to Larsson $(1986,31)$, the number of participants in a qualitative study is typically 20-50 participants.

This qualitative survey (Morse, 2010, 339-352) was conducted in two parts using a questionnaire in one university in south-western Finland over three years (2006, 2009, 2010). The questionnaire was pre-tested by biology student teachers. They answered the same questions what were used in the present study. Minor changes were made based on the feedback. 
A combination of quantitative and qualitative methods (a mixed approach; Punch, 2005) was used to get a holistic view of the participants' conceptions. The Likert scale levels $1-5$ were used in the quantitative part. In the open question part, the EPT were asked What do you find important in teaching and management of biology to be able to provide adequate learning to Finnish elementary school pupils? and What should pupils know about Nature? The data was analysed using inductive content analysis (Elo \& Kyngäs, 2008).

\section{The Analyses}

The EPTs' answers were listed using a running number each year (e.g. 55/2009 means the answer of the 55th EPT's answers to the open questions). The EPT mentioned totally 936 important issues which were divided into content categories and further into six main categories and subcategories. One answer could be included in more than one category. The inductive content analyses were carried out in three phases. The six main categories were remained unchanged during all phases. Pair-wise comparisons were made between the six main categories using $\chi^{2}$ - goodness-of-fit test.

In the first phase, the main concepts were identified, and "rough categories" were formed by two researchers independently. In the second phase, the inter-rater reliability was measured (Weber, 1990). Based on it, the researchers shared unanimous views in the majority of cases ( $89 \%)$. In the third phase the categories were harmonised and double checked by both researchers together. It was not always easy to divide the data into the subcategories due to confusion regarding what was really important or what exactly was meant to be important or due to an answer being close to both subcategories. When the overlapping concepts caused disagreements in classification these contradictions led the researchers to modify the classification categories and to test different classification alternatives. In these cases, the answers were interpreted according to the thinking of the EPT (though the used biological concept was wrong) and always in favour of the EPT; e.g. subcategory Species identification/species recognition was placed into two different categories: knowledge and skills. These two core contents were divided into two subcategories and under two different main categories when analyzing further. Into the category Species recognition also the core content Species knowledge was added. Contradictions were also found concerning subcategory Concepts. This category was left in classification in upper category Facts, because it includes expressions, which reflect situations where concepts are taught as a fact such as defined in dictionaries. Finally, the categories were tested using a chi-squared test bearing in mind the theoretical frame of the study (Elo \& Kyngäs, 2008).

\section{The Study Group}

The number of the participants was 87 in 2006, 94 in 2009, and 86 in 2010, none of the requested participants refused to take part to the study. Before this survey, all the participants had studied the same courses, e.g. sociology of education and some educational theories, during the first autumn term of their university studies. Pedagogical studies in biology started during the first spring term. All EPT had studied a minimum of two compulsory courses in biology in upper secondary school. According to NCC for upper secondary schools (Opetushallitus, 2003), the courses were: Living things (inquiry-based study methods, biodiversity, evolution, and ecology) and Cell and heredity (Niemi et al., 2012). During matriculation for the university, they all had taken a test concerning science and logical thinking.

According to the Finnish education system, every student needs to pass the nationally standardized student exam at the end of the upper secondary school. The studies in upper secondary school, lower secondary school, and elementary school are based on knowledge of several academic subjects (Opetushallitus, 2003, 2004; Niemi, Toom, \& Kallioniemi, 2012). Therefore, EPT have a wide background in CK when they start their university studies. 
For the background knowledge, the EPT were asked to self-estimate their perceived knowledge concerning seven biological scores: (a) structure of living organisms, (b) vital function of living organisms, (c) food chain and food web, (d) species identification and species recognition, (e) tree of life and system of organisms, (f) nature and the seasons, and (g) different ecosystems. The Likert scale from 1-5 was used. These scores were also used in forming a subcategory of the main knowledge (see later A3) in this study.

\section{RESULTS}

\section{The Elementary Pre-Service Teachers Perceived Knowledge}

The EPT self-estimated perceived knowledge of biology to be marginal or fair concerning seven biological scores (Figure 1). Good or excellent estimations were given by $21 \%$ of the participants. The structure (a) and vital function of living organism (b), species identification and species recognition (d), and the tree of life and system of organisms (e), got the lowest estimations. There were no big differences in the perceived knowledge levels between the EPT groups from the different study years.

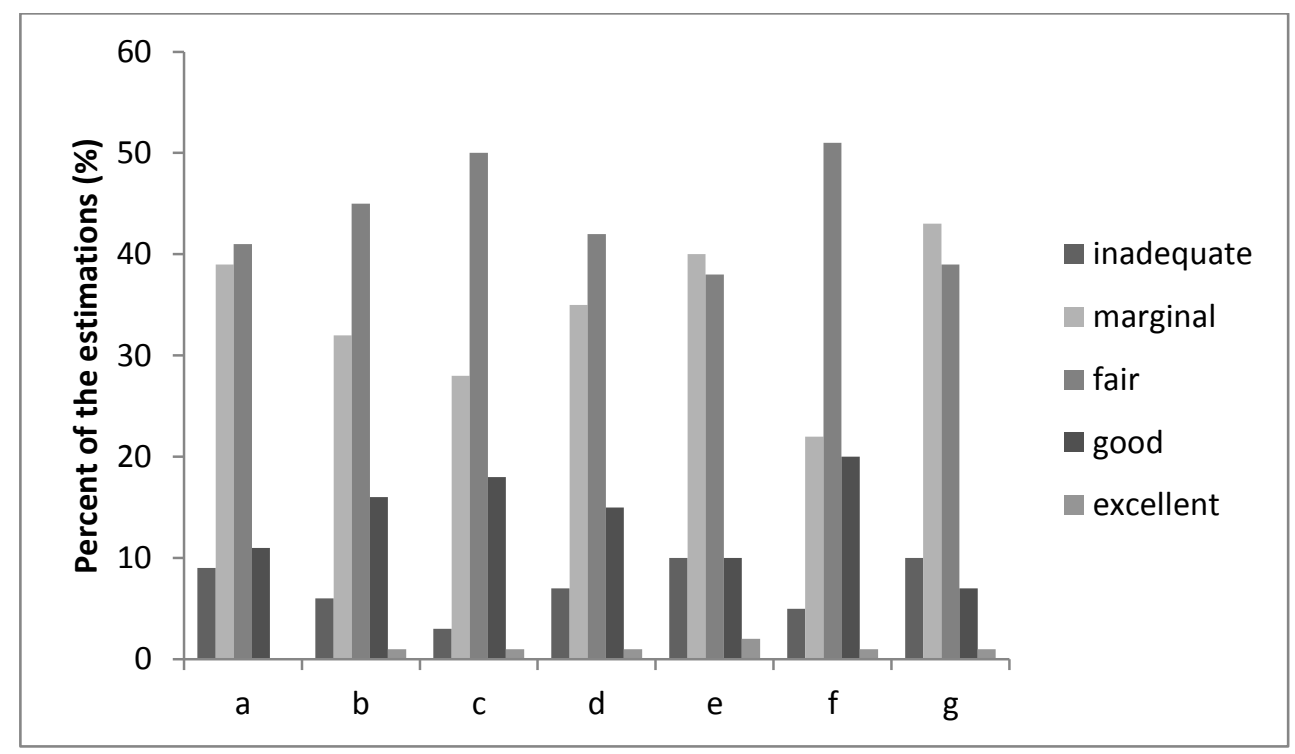

Figure 1. The distribution of the EPTs' $(n=267)$ self-estimations of their perceived knowledge concerning biological scores (a) structure of living organisms, (b) vital function of living organisms, (c) food chain, food web, (d) species identification and species recognition, (e) tree of life and system of organisms $(f)$ Nature and the seasons, and $(g)$ different ecosystems (the Likert scale levels: 1 inadequate, 2 marginal, 3 fair, 4 good, 5 excellent).

\section{Matters the Elementary Pre-service Teachers Mentioned to be Important in the Teaching and Management of Biology for Elementary School Pupils}

The six main categories of the important issues ( $n=936)$ mentioned by the EPT $(n=267)$ were: A) Knowledge, referring to BCK; B) Skills; C) Experiences; D) Attitudes; E) Teaching, referring, for example, to specific methods; and F) Others. Regarding the subcategories (Figure 2) of the two main categories A and B, the first main category of Knowledge (A) reflected important issues such as subcategories (A1) knowledge of Facts, referring to a superficial knowledge of facts concerning nature; (A2) knowledge of Deeper understanding the function of nature; and (A3) knowledge of EPSs' performance in biological scores based on the self-estimation (the same as scores in the 
perceived knowledge); and the second main category Skills (B) reflected Functional skills (B1), such as skills of moving and behaving in nature or skills of information retrieval; (B2) Subject-specific skills, such as species identification, natural scientific observation skills, or natural scientific thinking skills (thinking skills directly connected to biology learning); and (B3) general Thinking skills such as problem-solving skills or conceptual change.

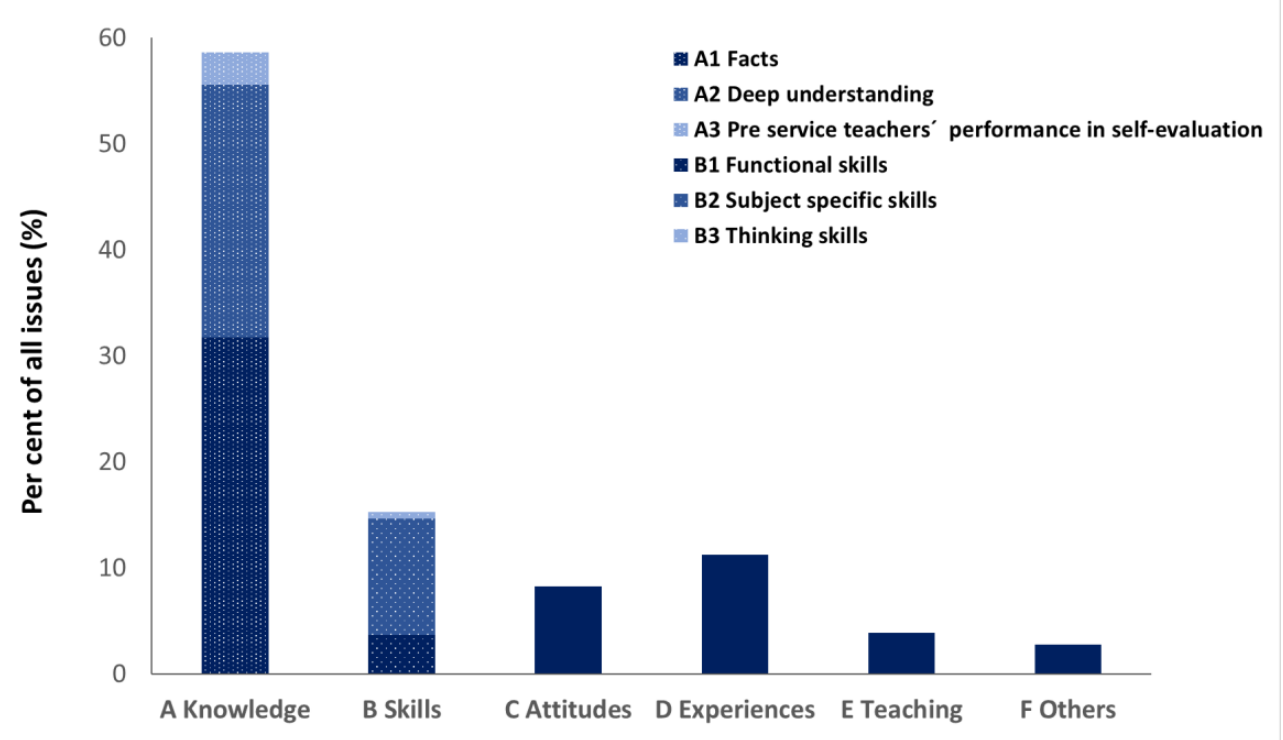

Figure 2. The six main categories $(A-F)$ of the important issues ( $n=936)$ mentioned by the EPT $(n=267)$ and the subcategories of Knowledge (A1, A2, A3) and Skills (B1, B2, B3).

BCK (A) comprised $60 \%$ of all issues, Skills (B) $15 \%$, Experience (D) $11 \%$, and the rest of the main categories comprised less than $10 \%$ of important issues. Issues concerning the main category of knowledge were mentioned significantly more often than issues concerning other categories.

The EPTs' answers included 549 issues concerning BCK (A) including Facts (A1) and Deeper understanding the function of nature (A2), and 29 issues referring straight to perceived knowledge scores (A3). The answers included 143 issues concerning Skills (B) including Functional skills (B1) and Subject-specific skills (B2), and 6 issues concerning general Thinking skills (B3). The answers also included 77 issues concerning Attitudes (C), such as crucial in sustainable development education (e.g. nature is seen valuable in itself, not only for its utilitarian values); 105 issues concerning Experiences (D), such as empathy with nature; 36 issues concerning Teaching (E); and finally 26 other issues (F), which could not be classified into the other categories. (Table 1.) 
Table 1. The differences of the mentioned issues in pair-wise comparisons.

\begin{tabular}{lcc}
\hline & Frequence & Percent \\
\hline Knowledge & 549 & $58,7^{\mathrm{a}}$ \\
Skills & 143 & $15,3 \%^{\mathrm{b}}$ \\
Attitudes & 77 & $8,2 \%^{\mathrm{c}}$ \\
Experiences & 105 & $11,2 \%^{\mathrm{b}, \mathrm{c}}$ \\
Teaching & 36 & $3,8 \%^{\mathrm{d}}$ \\
Other & 26 & $2,8 \%^{\mathrm{d}}$ \\
\hline
\end{tabular}

Each superscript letter denotes a subset of categories

whose proportions do not differ significantly from each

other at the , 05 level.

The Detailed Issues Mentioned by Elementary Pre-service Teachers in Six Main Categories: Knowledge, Skills, Attitudes, Experiences, Teaching, and Others

The main category Knowledge (A) referred to BCK, and the subcategory Facts (A1) included issues such as having superficial knowledge of facts concerning nature, or species knowledge, species identification, basic biology, e.g. the structure and function of living organisms and other issues (A1) such as Photosynthesis, Human biology, Knowledge of neighbourhood nature, Forests and forest types, Concepts, Biotic and Abiotic issues, Exploration of natural phenomena, and Cell functions (Table 2).

The subcategory Deeper understanding the function of nature (A2) contained answers concerning the function of ecosystems, food chains, the environment, and other issues (A2) such as evolution. Subcategory (A3) included answers connected to biological scores (the same as perceived knowledge scores). These answers dealing with the biological scores were examined separately, because the EPT were able to read these matters straight from the questionnaire.

\section{Examples of the EPTs' answers concerning the main category Knowledge (A)}

Function of nature, meaning of conservation, animal, and plant species. (19/2006)

It is important to learn natural phenomena; also, conservation, habitat, interactions and ecological lifestyle are important. (7/2009)

Man's role both as a part of nature and as a cofactor influencing the nature. Understanding the different kind of biological structures and functions: Via species knowledge to biodiversity". 15/2009

Knowledge of species, human biology, species reproduction, and nature as a unity: Everything affects everything else. (88/2009)

The main category Skills (B) also contained three subcategories (Table 3): Functional skills (B1), Subject-specific skills (B2) and General thinking skills (B3) such as problem-solving skills and conceptual change. The functional skills most often mentioned were skills of moving and behaving in nature. 
Table 2. Detailed issues in the main category Knowledge (A) mentioned by the EPT ( $n=267)$. The subcategories were (A1) Facts, (A2) Deeper understanding the function of nature, and (A3) all issues concerning the categories "biological scores" (the same as perceived knowledge scores). Other issues comprised, for example, (A1) photosynthesis and (A2) evolution. The percentages have been counted from all answers (totally 549) concerning knowledge.

\begin{tabular}{|l|l|r|}
\hline A Knowledge & Issues in subcategories & $\%$ \\
\hline (A1) Facts & Species knowledge & 17,9 \\
& The structure and function of living organisms & 8,0 \\
& Seasons & 7,5 \\
& Finnish nature and its special characteristics & 6,9 \\
& Other issues & 13,8 \\
(A2) Deeper Understanding the & & \\
function of nature & Nature as a system and the function of nature & 10,6 \\
& Ecosystems and how they function & 10,2 \\
& Food chains and food webs & 5,3 \\
& Other issues & 14,6 \\
(A3) Biological scores & Issues concerning biological scores & 5,3 \\
\hline
\end{tabular}

Table 3. The detailed issues in the main category Skills (B), Functional skills (subcategory B1), Subject-specific skills (subcategory B2), and General thinking skills (subcategory B3). Other issues in the category of Skills (other issues B1) comprised skills of information retrieval and skills needed in the field of education for sustainable development and conservation. Other issues (B2) comprised the ability to read the Nature and skills of classifying and comparison. The percentages have been counted from all answers (totally 149) concerning skills.

\begin{tabular}{|l|l|r|}
\hline B. Skills & Issues in subcategories & $\%$ \\
\hline (B1) Functional skills & Skills of moving and behaving in nature & 18,2 \\
& Other issues & 5,6 \\
& Species identification & 50,3 \\
& Observing & 8,4 \\
& Natural scientific thinking & 7,0 \\
(B3) General thinking skills & O.g. problem solving, conceptual change & 6,3 \\
\hline
\end{tabular}


The subject specific skills (B2) most often mentioned were species identification skills and skills of making biological observation and natural scientific thinking, for example, systemic thinking in biology (information retrieval in biological matters). Other issues in this subcategory were "reading the nature" and biological classification and comparison. Skills needed in education for sustainable development were also mentioned.

\section{Examples of the EPTs' answers concerning the main category Skills (B)}

It is important to motivate pupils to study/survey/research, observe, and become enthusiastic about nature, and to encourage them to both travel on foot in the nature and understand nature. It is also important to identify the most common species of neighbourhood: Know where they live, how they feed and eat. (94/2009)

It is important to learn the right attitude, the way to obtain information and subject-specific thinking. (57/2010)

To understand the general view, it is also important to travel on foot in nature, give safety education to pupils, and teach them to be prepared for weather changes and accidents... (20/2010)

Teaching of attitudes (the main category C, totally 77), for example towards nature, was brought up by the EPT. The following examples reflect how important they feel is respect for nature.

\section{Examples of answers in the main category Attitudes (C)}

What kind of relationship should one have with nature: respect, conservation and sustainable development. (20/2006)

The most important thing is to learn to respect nature. $C_{51 / 2010}$

The importance of the experiences of elementary school pupils was also mentioned.

The experiences formed their own category (D, totally 105)

Basic things, not just facts. Knowledge of species, knowledge of great biological unities, experimental learning, and experiences. 31/2006

Biodiversity, how to act in nature, conversation and student-centred learning, excursions, experiences (11/2009)

The EPTs' answers (the main category Teaching E, totally 36) contained issues concerning, for example, concrete methods and motivation.

Teachers should concretize things as well as possible. It is important to use a lot of supplementary material. (21/2006)

Teaching should be practical. Teacher should encourage pupils to go to the wild and explore nature. (64/2006)

The category Others ( F, totally 26) contained issues that could not be included in any other main category, such as some matters mentioned in the NCC.

\section{The Answers by the Groups}

Five different issues were mentioned by the EPT often. The two most common issues in every year (Table 4) were species knowledge (A1) and species identification (B2). In the rest of the answers there was variation between the groups. 
Table 4. The five most common issues in the EPTs' answers $(n=267)$ and the yearly variation in 2006 $(n=87), 2009(n=94)$, and $2010(n=86)$.

\begin{tabular}{|c|c|c|c|c|}
\hline Issue lyear & ALL $(n=267)$ & $2006(n=87)$ & $2009(n=94)$ & $2010(n=86)$ \\
\hline $\begin{array}{l}\text { 1. Most } \\
\text { common }\end{array}$ & species knowledge (98) & $\begin{array}{l}\text { species knowledge } \\
(22)\end{array}$ & species knowledge (40) & species knowledge (36) \\
\hline $\begin{array}{l}\text { 2. Most } \\
\text { common }\end{array}$ & species identification (72) & $\begin{array}{l}\text { species } \\
\text { identification (17) }\end{array}$ & species identification (3 & species identification (25) \\
\hline $\begin{array}{l}\text { 3. Most } \\
\text { common }\end{array}$ & $\begin{array}{l}\text { nature as a unity; } \\
\text { understanding the functions } \\
\text { of nature ( } 58 \text { ) }\end{array}$ & $\begin{array}{l}\text { the structure and } \\
\text { function of living } \\
\text { organism (18) }\end{array}$ & $\begin{array}{l}\text { ecosystems, e.g. their } \\
\text { functions (29) }\end{array}$ & $\begin{array}{l}\text { nature as a unity; } \\
\text { understanding the functions } \\
\text { of nature (23) }\end{array}$ \\
\hline $\begin{array}{l}\text { 4. Most } \\
\text { common }\end{array}$ & $\begin{array}{l}\text { ecosystems, e.g. their functions } \\
(56)\end{array}$ & $\begin{array}{l}\text { respecting nature } \\
(16)\end{array}$ & $\begin{array}{l}\text { nature as a unity; } \\
\text { understanding the } \\
\text { functions of nature (25) }\end{array}$ & $\begin{array}{l}\text { ecosystems, e.g. their } \\
\text { functions (21) }\end{array}$ \\
\hline $\begin{array}{l}\text { 5. Most } \\
\text { common }\end{array}$ & $\begin{array}{l}\text { the structure and function of } \\
\text { living organisms (44) }\end{array}$ & $\begin{array}{l}\text { food chains and } \\
\text { webs (11) and } \\
\text { seasons (11) }\end{array}$ & $\begin{array}{l}\text { Finnish nature and its } \\
\text { special characteristics } \\
\text { (20) }\end{array}$ & $\begin{array}{l}\text { the structure and function } \\
\text { of living organisms (18) }\end{array}$ \\
\hline
\end{tabular}

The three other most common answers were connected to the ecology and function of nature, except for one, which was connected to the structure and function of living organisms.

\section{Discussion}

The survey investigated what kind of conceptions EPT have concerning the issues they find important in teaching and management of biology to provide adequate learning for Finnish elementary school pupils.

The main findings of this study were firstly, that the issues mentioned by the individual EPT regarded as important in teaching and management of biology were inconsistent. Only species knowledge and species identification were mentioned every year. This finding supports the results of Käpylä et al. (2009) who stated that it is difficult for EPT to find the main topics and concepts.

Secondly, the issues regarded important by the EPT were strongly related to BCK, especially to facts. The most prevalent issues presented by all EPT were fundamental facts (CK), including species knowledge, the structure and function of living organisms, Finnish nature and its special characteristics, and biological phenomena such as photosynthesis. Additionally, ecological issues such as the food chain or food web, and understanding of the functions of nature as well as issues in human biology were mentioned. These were issues the EPT regarded as basic knowledge of biology like the EPTs in the previous studies of Palmberg and others (2012, 2016). The same issues were studied during their school time (Opetushallitus, 2003), and same ones are focused in CTE (Kasvatustieteiden tiedekunta, 2014). To provide adequate learning for Finnish elementary school pupils these issues, they think, are necessary to teach also nowadays. So, their conceptions are in line with NCC (Opetushallitus, 2015, 239-241, 439-441). 
At the beginning of their pedagogical studies, the EPT were clearly CK oriented - only a few of them were student oriented. The result supports findings of the study by Huiping (2011) otherwise but Huiping also found learning oriented teachers. Based on our results, first year EPT seemed to focus more on teaching than on pupils' learning. All their conceptions show teacher thinking where a teacher is in the centre of the classroom organization. The teacher-centred approach is associated with the transmission of knowledge (Brown, 2003, 49). According to the modern conceptions concerning education the pupils are at the centre of classroom organization and the teaching should concentrate more on pupils' learning needs, strategies and styles (Volet et al., 2013). Also in the NCC (Opetushallitus, 2014, 2015, 10-17) and in the CTE (Kasvatustieteiden tiedekunta, 2014), the learner-centred approach is emphasized.

The important issues were divided into six main categories, of which species knowledge and species identification were the most commonly mentioned by the EPT in every study year. A reason for the result could partly be that these topics were also indicated in the self-estimation questions. However, a more likely explanation is that both knowledge of species and species identification as basic elements of biology education are natural starting points and important fundamental parts of biodiversity education and sustainable development education (Opetushallitus, 2014, 2015, 239-241, 439-441). A certain level of knowledge of species is needed for understanding ecology (Magntorn \& Helldén, 2005). Furthermore, knowledge of species is one of the factors that best promote interest in and understanding of biodiversity, environmental issues, and sustainable life style (Lindemann-Matthies, 2006).

Käpylä et al. (2009) and Magnusson et al. (1999), have shown that a certain amount of CK is needed for successful PCK. In this study, only few EPT were able to connect BCK to PCK. Most EPT see BCK to be stable and conserved like in Finnish schoolbooks including mainly facts and not knowledge based on the newest research results (Mikkilä-Erdmann, 2002; Mikkilä-Erdmann et al., 1999, 436438; Wikman, 2004). Only few participants presented examples of the importance of procedural knowledge. Procedural knowledge is about how to think (Andersson, 1990), and it is linked with the performance change in knowledge, skills and tasks (LeFevre et al., 2006). The EPT who mentioned these examples showed an understanding of nature of science which is necessary when applying scientific understandings to life situations involving science (Lederman, 1992, 2007; OECD. 2007).

Thirdly, in the answers of the EPT, the types of PCK presented by Shulman (1987) were found. For example, the importance of experiences, practical knowledge, field education, and pedagogical skills were mentioned by some EPT. They found important to give elementary pupils opportunities to learn to "create their own biological knowledge", for example via educational biological plays or games or visualised virtual learning environments. These ideas are in line with the guidelines for future science education (Fadel et al., 2015) and NCC (Opetushallitus, 2014, 2015, 10-17). However, only few EPT mentioned the importance of methods typical to biology, which are important when developing subject-specific learning skills (Ennis, 1989; Haapasalo, 2004). This implies that at the beginning of their educational studies, most EPT did not realize the meaning of teaching and learning methods for the development of scientific thinking of pupils. The importance of evaluation of either CK or study processes was not mentioned at all. However, objective-based evaluation and importance of feedback for pupils have been mentioned in NCC (Opetushallitus, 2015, 46-56, 271-274, 239-241, 439-441), and the principles of research-based evaluation have been taught in biology in the teacher education (Kasvatustieteiden tiedekunta, 2014).

The reliability of a qualitative study depends on trustworthiness of the procedures and data generated (Stiles, 1993). For this reason, the research methods and results are described thoroughly (Miles \& Huberman, 1994). As the description of the methods shows, identifying PCK data was not easy, partly because of the study design (it was not rational to ask the first year EPT directly about PCK in biology) and partly because PCK is not explicitly defined (Käpylä et al., 2009). According to Loughran (2001), 
PCK is largely tacit, and teachers have difficulties in explicating it. All the main six categories included answers, which could have been connected to PCK. However, the conceptions concerning PCK were written at a very general level and therefore it can be assumed that even before pedagogical studies, the EPT had an idea that there is something important in teaching and learning besides BCK, but they did not present precise examples how to teach or learn to conduct biological observations. Käpylä et al. (2009) proposed that PCK is a separate domain and our findings support the idea that PCK should be taught explicitly like CK.

Concerning validity, quotes from the EPTs' conceptions are presented in order to show that the results are credible from the perspective of the participants (Johnson 1997). Some questions in the questionnaire might have an influence on the answers; for example, if the EPT were first asked what is important in teaching biology in school, and the second question was what pupils should know about nature. Also the questions concerning perceived knowledge might have influenced on the EPTs' answers to what is important. However, these ones did not create interpreting problems; based on the test, only $5.3 \%$ of all the answers in the category of Knowledge were connected directly to the biological scores. For ensuring confirmability of categorization the inter-rated reliability was measured (Weber, 1990), and it was good (unanimity 89\%). For transferability the research context is described thoroughly (Cresswell, 2003).

\section{CONCLUSION}

Based on the study, there is much work to do in order to make the elementary biology education and its role in sustainable development education more understandable. The EPT emphasized biological facts included in the NCC but they had incomplete view of the totality concerning elementary biology education. The EPT estimated their perceived knowledge of biology to be mostly marginal or fair, without big differences between the participant groups from the different study years. So, it seems that the EPT do not trust in their abilities to teach and manage biology (cf. Bandura, 1986). The one challenge for science educators is to find ways to change EPTs' focus from detailed, fact stressed issues to the basic knowledge of biology. Another challenge is how to support EPT so that they understand biology as a continuously changing subject even at the elementary level. It should also be discussed how to remodel BCK for better consistency with PCK, for example, via study methods, subject specific thinking, and evaluation processes. In particular, there should be studies on how to manage these demands using digital tools.

\section{REFERENCES}

Abd-el-Khalick, F. (2006). Preservice and experienced biology teachers' global and specific subject matter structures: Implications for conceptions of pedagogical content knowledge. Eurasia Journal of Mathematics, Science and Technology Education, 2(1), 1-29.

Abell, S.K. \& Smith, D.C. (1994). What is science? Preservice elementary teachers' conceptions of the nature of science. International Journal of Science Education, 16(4), 475-487.

Andersson, J.R. (1990). Cognitive psychology and its implications (3rd ed.). A series of books in psychology. New York, NY, US: W.H. Freeman/Times Books/ Henry Holt \& Co.

Andree, M. (2007). Den levda läroplanen. En studie av naturorienterande undervisningspraktiker $i$ grundskolan. Lärarhögskolan i Stockholm. Studies in Educational Sciences 97. Stockholm: HLS Förlag.

Appleton, K. (2003). How do beginning primary school teachers cope with science?: toward an understanding of science teaching practice. Research in Science Education, 33, 1-25.

Bandura, A. (1986). Social foundations of thought and action: A social cognitive theory. Englewood Cliffs, NJ: Prentice Hall.

Bandura, A. (2004). Health promotion by social cognitive means. Health Education \& Behavior, 
$31(2), 143-164$.

Bencze, L. \& Hodson, D. (1999). Changing practice by changing practice: Towards more authentic science and science curriculum development. Journal of Research in Science Teaching, 36(5), 521-539.

Bishop, K., \& Denley, P. (2007). Learning science teaching: Developing a professional knowledge base. Berkshire, UK: Open University Press.

Boström, L. (2004). Lärande \& Metod. Lärstilsanpassad undervisning jämfört med traditionell undervisning i svensk grammatik, Avhandling i pedagogik. Jönköping, Sweden: Helsingfors universitet och Högskolan för lärande och kommunikation.

Brown, K.L. (2003). From Teacher-Centered to Learner-Centered Curriculum: Improving Learning in Diverse Classrooms. Education, 124(1), 49-54.

Carlesen, W. (1991). Effects of new biology teachers' subject-matter knowledge on curricular planning. Science Education, 75, 631-647.

Committee on Science and Mathematics Teacher Preparation. (2001).

Cresswell, J.W. (2003). Research design; qualitative, quantitative and mixed methods approaches. Thousand Oaks: Sage.

Davis, E.A., Petish, D., \& Smithey, J. (2006). Challenges new science teachers face. Review of Educational Research, 76(4), 607-651.

De Bono, E. (1969). The Mechanism of Mind. London: Jonathan Cape.

Elo, S., \& Kyngäs, H. (2008). The qualitative content analysis process. Journal of Advanced Nursing, 62(1), 107-115.

Ennis, R.H. (1989). Critical thinking and subject specificity: Clarification and needed research. Educational Researcher, 18(3), 4-10.

European Commission (2004). Europe Needs More Scientists: EU Blueprint for Action. Retrieved $13^{\text {th }}$ March 2016 from http://ec.europa.eu/research/press/2004/pro204en.cfm.

Evagorou, M., Dillon, J., Viiri, J., \& Albe, V. (2015). Pre-service science teacher preparation in Europe: Comparing pre-service teacher preparation programs in England, France, Finland and $\mathrm{Cy}-$ prus. Journal of Science Teacher Education, 26, 99-115.

Fadel, C., Bialik, M., \& Trilling, B. (2015). Four-dimensional education: The competencies learners need to succeed. 1st edition. Boston, MA: Center for Curriculum Redesign.

Frändberg, B., \& Bach, F. (2009). Naturorienterande ämnen i årskurs 4. En analys av lärares och elevers uppfattningar om ämnesinnehåll och undervisning i TIMSS 2007. Analysrapport, 323. Skolverket.

Grossman, P.L. (1990). The making of teacher: Teacher knowledge and teacher education. New York: Teachers College Press.

Haapasalo, L. (2004). Pitääkö ymmärtää voidakseen tehdä vai pitääkö tehdä voidakseen ymmärtää? In P. Räsänen, P. Kupari, T. Ahonen, \& P. Malinen (Eds.) Matematiikka - näkökulmia opettamiseen ja oppimiseen (pp. 50-83). Jyväskylä, Finland: Niilo Mäki -Instituutti.

Huiping, Y. (2011). Exploring teachers' personal practical knowledge about teaching reading comprehension in English - A study of teacher knowledge at a University in China. Retrieved $4^{\text {th }}$ November 2015 from http://www.diva-portal.org/smash/get/diva2:426266/fulltexto1.

Hurd, P.D. (2002). Modernizing science education. Journal of Research Science Teaching, 39, 3-9.

Johnson, R.B. (1997). Examining the validity structure of qualitative research. Education, 118(2), 282-292.

Kasvatustieteiden tiedekunta (2014). Kasvatustieteiden tiedekunnan opinto-opas 2014-2016. Turku: Painosalama.

Khosa, D.K. \& Volet, S.E. (2014). Productive group engagement in cognitive activity and metacognitive regulation during collaborative learning: can it explain differences in students' conceptual understanding? Metacognition and Learning, 9(3), 287-307.

Käpylä, M., Heikkinen, J-P., \& Asunta, T. (2009). Influence of content knowledge on pedagogical content knowledge: The case of teaching photosynthesis and plant growth. International Journal of Science Education, 31(10), 1395-1415. 
Larsson, S. (1986). Qualitative Analysis. The example Phenomenography. Lund: studentlitteratur. (In Swedish.)

Lavonen, J. (2013). Building Blocks for High Quality Science Education: Reflections based on Finnish Experiences. LUMAT 1(3), 299-314.

Lavonen, J., \& Juuti, K. (2012). Science at Finnish compulsory school. In H, Niemi, A. Toom, \& A. Kallioniemi (Eds.) Miracle of education: The principles and practices of teaching and learning in Finnish schools (pp. 131-146). Rotterdam: Sense Publishers.

Lederman, N.G. (1992). Sudents' and teachers' conceptions of the nature of science: A review of research. Journal of Research in Science Teaching, 29, 331-359.

Lederman, N.G. ( 2007). Nature of science; Past, present, and future. In S.K. Abell, \& N.G. Lederman (Eds.) Handbook of research on science education (pp. 831-879). Mahwah, NJ: Lawrence Erlbaum Associates.

LeFevre, J. A., Smith-Chant, B.L., Fast, L., Skwarchuk, S.L., Sargla, E., Arnup, J.S., Penner-Wilger, M., Binsanz, J., \& Kamawar, D. (2006). What counts as knowing? The development of conceptual and procedural knowledge of counting from kindergarten through Grade 2. Journal of Experimental Child Psychology, 93(4), 285-303.

Lindemann-Matthies, P. (2006). Investigating nature on the way to school: Responses to an educational programme by teachers and their pupils. International Journal of Science Education, 28, 895-918.

Loughran, J., Milroy., Berry, A., Gunstone, R., \& Mulhall, P. (2001). Documenting science teachers' pedagogical content knowledge through PaP-eRs. Research in Science Education, 31, 289-307.

Lundin, M. (2007). Students' participation in the realization of school science activities. Nationella forskarskolan in naturvetenskapernas och teknikens didaktik. FontD, Institutionen för samhälls och välfärstudier, Linköping University, Norrköping.

Magntorn, O. \& Helldén, G. (2005). Student-teachers' ability to read nature: Reflections on their own learning in ecology. International Journal of Science Education, 27(10), 1229-1254.

Magnusson, S., Krajcik, J., \& Borko, H. (1999). Nature, sources, and development of pedagogical content knowledge for science teaching. In J. Gess-Newsome \& N.G.Lederman (Eds.) Examining pedagogical content knowledge: The construct and its implications for science education (pp. 95-132). Dordrecht: Kluwer Academic Publishers.

Mellado, V. (1998). The classroom practice of pre-service teachers and their conceptions of teaching and learning science. Science Education, 82, 197-214.

Mikkilä-Erdmann, M. (2002). Textbook text as a tool for promoting conceptual change in science. Turun yliopiston julkaisuja, Humaniora, B 249.

Mikkilä-Erdmann, M., Olkinuora, E., \& Mattila. E. (1999). Muuttuneet käsitykset oppimisesta ja opettamisesta - haaste oppikirjoille. Kasvatus, 3o(5), 436-448.

Miles, M. \& Huberman, A. (1994). Qualitative Data Analysis: an expanded source book. Thousand Oaks: Sage.

Morse, J.M. (2010). Procedure and practice of mixed method design. Maintaining control, rigor and compexity. In A. Tashakkori \& C. Teddlie (Eds.) Handbook of mixed methods in social and behavioural research (pp. 339-352). London: Sage Publications.

Niemi, H., \& Jakku-Sihvonen, R. (2006). Research-based teacher education. In R. Jakku-Sihvonen \& H. Niemi (Eds.) Research-based teacher education in Finland - Reflections by Finnish teacher educators (pp. 31-50). Turku: Painosalama.

Niemi, H., Toom, A., \& Kalliomäki, A. (2012). Miracle in education, Principles and practices of teaching and learning in Finnish schools. Rotterdam: Sense Publishers.

Nilsson, P. \& Loughran, J. (2012). Exploring the Development of Pre-Service Science Elementary Teachers' Pedagogical Content Knowledge. Journal of Science Teacher Education, 23, 699-721.

Norris, S.P. \& Ennis, R.H. (1989). Evaluating critical thinking. Pacific Grove, CA: Midwest Publicatons.

OECD. (2007). PISA 2006. Science competencies for tomorrow's world. Volume I: Analysis. Paris: OECD. 
Opetushallitus (The National Board of Education) (2003, 2004). The Finnish national core curriculum for upper secondary schools. Helsinki: Opetushallitus.

Opetushallitus (The Finnish National Board of Education) (2014, 2015). The Finnish Core curriculum for basic education. Tampere: Suomen Yliopistopaino. (In Finnish.)

Opwood, G. \& Souque, J. (1985). Towards the renewal of Canadian science education. Science Education, 69, 625-636.

Osborne, J. \& Dillon, J. (2008). Science Education in Europe: Critical Reflections. London: The Nuffield Foundation.

Otero, V.K. \& Nathan, M. (2004). Elementary Pre-Service Teachers' Conceptions of Student Prior Knowledge. Physics Education Research Conference Proceedings, V, 720, (pp. 141-144).

Palmberg, I. (2012). Artkunskap och intresse för arter hos blivande lärare för grundskolan. NorDiNa, $8(3), 244-257$.

Palmberg, I., Jeronen, E., Svens, M., Yli-Panula, E., Andersson, J., \& Jonsson, G. (2012). Blivande läräres (åk 1-6) baskunskaper i Danmark, Finland och Sverige. Kunskaper och uppfattningar om människans biologi. NorDiNa, 1(11), 54-70.

Palmberg, I., Berg, I., Jeronen, E., Kärkkäinen, S., Norrgård-Sillanpää, P., Persson, C., Vilkonis, R., \& Yli-Panula, E. (2015). Nordic-Baltic Student Teachers' Identification of and Interest in Plant and Animal Species - The Importance of Species Identification and Biodiversity for Sustainable Development. Journal of Science Teacher Education, 26, 549-571.

Palmberg, I., Jonsson, G., Jeronen, E., \& Yli-Panula, E. (2016). Student teachers' conceptions and understanding of basic knowledge in ecology in Denmark, Finland and Sweden. NorDiNa, 12(2), 197-217.

Punch, K.F. (2005). Introduction to social research: Quantitative and qualitative approaches. London: SAGE.

Shulman, L.S. (1987). Knowledge and teaching: Foundations of the new reform. Harvard Educational Review, 57(1), 1-22.

Stiles, W.B. (1993). Quality control in qualitative research. Clinical Psychology Review, 13(6), 593618.

Tobias, S. \& Everson, H.T. (1996). Assessing Metacognitive Knowledge Monitoring. College Board Report, 96-101, New York: College Board.

Uitto, A., Kärnä, P., \& Hakonen, R. (2013). Työ- ja toimintatapojen yhteys biologian osaamiseen ja biologiasta pitämiseen peruskoulussa. LUMAT 1(3), 263-278.

Vauras, M., Lehtinen, E., Volet, S., \& the SciLes research group. (2014). Science learning environments for future schools. Scaffolding disciplinary engagement co-construction and -regulation of disciplinary understanding through digital tools. The emotional, social and cultural aspects of collective action: Joint seminar with Academy programmes SKIDI-KIDS, MIND and TULOS, Tallinna 27.-28.2014. Retrieved 12th November 2015 from http://www.aka.fi/globalassets/awanhat/documents/ohjelmat/vauras-tallinn-28112014.pdf

Volet, S., Vauras, M., Khosa, D., \& Iiskala, T. (2013). Metacognitive regulation in collaborative learning: Conceptual developments and methodological contextualizations. In S. Volet \& M. Vauras (Eds.) Interpersonal regulation of learning and motivation. Methodological advances (pp. 67101). New York: Routledge.

Weber, R.P. (1990). Basic Content Analysis. Second edition. Newbury Park CA: Sage.

Wikman, T. (2004). På spaning efter den goda läroboken. Om pedagogiska texters lärande potential. Akademisk avhandling, Pedagogiska fakulteten vid Åbo Akademi, Åbo.

Yli-Panula, E., Hiilovaara-Teijo, M., \& Vauras, M. (2015). High school students' inquiry based collaborative learning in virtual marine science laboratory. Suomen ainedidaktisen tutkimusseuran julkaisuja, Ainedidaktisia tutkimuksia, 8, 135-152. https://helda.helsinki.fi 